\title{
Alicja Bartuś
}

Wyższa Szkoła Bankowa w Poznaniu

\section{Zbigniew Bartuś}

„Dziennik Polski”

\section{Pokusa etatyzmu Ile polityki w gospodarce - wymiar etyczny}

\section{Wprowadzenie}

W klasycznych koncepcjach filozoficznych człowiek bywa przedstawiany jako ktoś z natury dobry (jak u Rousseau) ${ }^{1}$ albo ktoś z natury zły (jak u Hobbesa) ${ }^{2}$. W Polsce przez ostatnich 16 lat rozwinął się całkiem odmienny - choć, jeśli spojrzymy wstecz, w dzieje ludzkości: wcale nie nowatorski - wariant tych koncepcji. Według niego, z natury dobry jest człowiek reprezentujący naszą partię, nasze ugrupowanie, naszą grupę interesów. Ten, kto w tej grupie się nie mieści, jest z natury zły.

Jedną z najbardziej znamiennych i dramatycznych konsekwencji tego dualistycznego spojrzenia na rzeczywistość społeczną i gospodarczą jest w III Rzeczypospolitej brak ciagłości władzy - co cztery lata (lub częściej) zupełnie zmienia się układ rządzący krajem, do władzy dochodzą formacje pozostające w totalnej opozycji do poprzedników; co więcej - zdobywają władzę właśnie dlatego, że swe główne hasła - i programy - opierają na zmasowanej krytyce oraz odrzuceniu wartości i działań utożsamianych z ludźmi dotychczas rządzącymi.

Wszystkie ugrupowania, które w ciągu 16 lat zdobyły władzę w III RP, szły po nią, głosząc hasła gruntownych zmian społecznych i gospodarczych. Wprawdzie różnie je rozumiały, ale poziom i temperatura radykalizmu były podobne u prącej ku władzy postkomunistycznej lewicy i u posolidarnościowej centroprawicy. Równie charakterystyczny, jak ów kampanijny radykalizm, był sposób, w jaki zwycięskie ugrupowania oswajały zastany system lub dawały mu się oswoić, „wchodząc w buty poprzedników”. U przeciętnego obywatela rodziło to - z reguły uzasadnione - wrażenie, że oto „nowi” wiele naobiecywali (,,jak zwykle”), a teraz i tak robią to, co „starzy”. W społeczeństwie rodziło to zniechęcenie do polityki i polityków w ogóle, a w szeregach wyborców, którzy poparli zwycięskie ugrupowanie, musiało się dodatkowo pojawić poczucie głębokiego zawodu, rozczarowania, a w końcu - poczucie, że zostało się zdradzonym.

Gdy spojrzeć na przepływ elektoratu z prawa na lewo i z powrotem w ostatnich 16 latach, łatwo zauważyć, że znaczna jego część była zdradzana wielokrotnie: raz zaufała dobrym ludziom z SLD

\footnotetext{
${ }^{1}$ Jean-Jacques Rousseau (1712-1778), francuski pisarz, filozof i pedagog, twórca koncepcji swobodnego wychowania. W traktacie Emil, czyli o wychowaniu (1762) zawarł zasady koncepcji naturalnego wychowania; pisał m.in.: „Wszystko jest dobre, co z rąk Stwórcy pochodzi, wszystko paczy się w rękach człowieka".

${ }^{2}$ Thomas Hobbes (1588-1679), angielski filozof. Według Hobbesa każdy człowiek jest z natury egoista. Jeśli pozornie wszyscy są wolni, ludzie zaczynają z sobą walczyć (wojna każdego z każdym - bellum omnium contra omnes). Zamiast korzystać z wolności, każdy musi koncentrować się na przetrwaniu. Między wolnością a przetrwaniem istnieje zatem stały, nierozwiązywalny konflikt.
} 
i PSL, by potem wybrać AWS, po kolejnych czterech latach wróciła gremialnie do SLD, by następnie głosować na centroprawicę oraz partie wyrażające najgłębszą frustrację, jak Samoobrona i LPR.

U podłoża poczucia zdrady leży właśnie ów manichejski podział świata: na ludzi „z natury dobrych” (swojaków) i ,z natury złych” (obcych). Z tego podziału zrodziła się koncepcja Rzeczypospolitej - państwa, które może być dobre tylko wtedy, gdy jest budowane i kontrolowane przez „ludzi z natury dobrych” - „swoich”. Państwo takie będzie uczciwe, etyczne, gospodarne, bo przecież tacy właśnie, uczciwi, etyczni i gospodarni sąjego gospodarze, czyli „swoi” („nasi”).

Liberałowie, którymi w kampaniach wyborczych 2005 r. straszyło się Polaków, uważają takie rozumowanie za czystą utopię. Ich zdaniem, to nie ,z natury dobrzy ludzie”, próbując kontrolować wszystkie dziedziny życia (w manichejskiej walce z siłami rzekomo „z natury złymi”), tworzą dobre, sprawne państwo, społeczeństwo i gospodarkę. To mechanizmy wolnego rynku i jasne, przejrzyste prawo sprawiają, że jednostki współpracują ze sobą dla dobra ogółu, budując wolne i solidarne społeczeństwo, zdrową, rozwijającą się, zapewniającą powszechny dobrobyt gospodarkę, czego efektem jest dobre państwo. Państwo jest silne siłą swych obywateli (gdy w koncepcjach antyliberalnych obywatele mają być ,silni siłą swego państwa”).

Liberalna koncepcja, fundamentalna w krajach, które odniosły ekonomiczny sukces, jak Stany Zjednoczone, Wielka Brytania czy ostatnio Irlandia, ściera się w Polsce od 16 lat z koncepcją etatystyczną (liberałowie określają ją mianem ,socjalistycznej”), zakładająca, że tylko pod ścisłą kontrolą państwa można zbudować powszechny dobrobyt. Oczywiście, autorzy tej etatystycznej koncepcji dodają zaraz, że uda się to wyłącznie wówczas, gdy odpowiednie pozycje w państwie zajmą odpowiedni ludzie, „ludzie z natury dobrzy”.

W praktyce okazuje się zawsze, że takich ludzi nie ma, a wszystkie kolejne ekipy, którym zaufali Polacy, dopuszczają się ,zdrady”. Dlaczego tak się dzieje?

Etatyści twierdza, że dlatego, iż na razie do władzy nie doszli odpowiedni, właściwi ludzie. Kiedy dojda, to wszystko natychmiast zmieni się na lepsze. Diagnoza liberałów jest zupełnie inna - ich zdaniem jedynym lekarstwem na ,zdradę” jest wyrwanie z rąk polityków i posłusznych im urzędników jak największej części władzy, zwłaszcza wtedy, gdy krępuje przedsiębiorczość. Można to zrobić wyłącznie poprzez stworzenie precyzyjnego i przejrzystego prawa oraz zniwelowanie bezpośredniego wpływu polityki na gospodarkę.

W tym miejscu skupimy się na jednej kwestii: politycznym uzależnieniu firm państwowych oraz spółek z udziałem Skarbu Państwa.

Typową opinię na ten temat, jaką można usłyszeć od pracowników średniego szczebla kierowniczego, można by wyrazić następującym cytatem jednego z pracowników: „System powiązań między polityką a gospodarkę jest dziś w Polsce taki, że niejeden święty, zamiast walczyć z nim, po prostu zacząłby z niego korzystać. A co dopiero mówić o nieświętych?"

Spółek z udziałem Skarbu Państwa jest w Polsce ponad 1400, w blisko 450 z nich Skarb Państwa ma stuprocentowe lub większościowe udziały, w pozostałych jest akcjonariuszem mniejszościowym, co - jak widać choćby na przykładzie Orlenu - nie oznacza wcale braku wpływu na decyzje personalne, i nie tylko. ${ }^{3}$

Na wyobraźnię przeciętnego Polaka najsilniej działają wynagrodzenia prezesów, np. kwota 200 tys. zł, jaką miał co miesiąc zarabiać prezes Orlenu. To wprawdzie więcej niż minister

\footnotetext{
${ }^{3}$ W końcu czerwca 2005 r. Minister Skarbu Państwa nadzorował 1474 spółki, w tym 449 jednoosobowe spółki Skarbu Państwa i 1025 spółek z częściowym udziałem Skarbu Państwa (źródło: Ministerstwo Skarbu Państwa).
} 
skarbu - rozdający (teoretycznie) karty w polskiej nafcie - zarabia przez cały rok, ale w kręgach top-biznesu są to pieniądze niewielkie. Wzięty i sprawdzony menedżer może je bowiem zarobić w nieuwiązanych politycznie zachodnich koncernach - bez rozgłosu, bez ryzyka wystawienia pod publiczny osąd.

Po co więc tacy ludzie - przyjaciele, koledzy oraz bliżsi i dalsi znajomi polityków - pojawiają się po każdych wyborach w owych 1400 spółkach z udziałem Skarbu Państwa? Oficjalne wytłumaczenie jest oczywiste: żeby bronić interesów państwa w tych firmach. Złośliwcy dopytują się w tym momencie: a o których Państwa chodzi?

\section{Co to znaczy: ,w imieniu państwa"}

Choć grubo ponad 90\% zatrudnionych Polaków pracuje w firmach prywatnych i utrzymuje $\mathrm{z}$ tej pracy całe rodziny, sektor publiczny pozostał w Polsce niezwykle mocny. ${ }^{4}$ Wytwarza jedną czwartą produktu krajowego brutto, co oznacza, że przechodzą przezeń olbrzymie pieniądze, z reguły bez charakterystycznego dla ,prywaciarzy” oglądania złotówki z obu stron. ${ }^{5}$ Liberalni ekonomiści podzielają dość powszechny pogląd, że w tym sektorze często ryzykuje się majątkiem publicznym, zarabiając pieniądze całkiem prywatnie.

Według ostatnich szacunków wartość mienia Skarbu Państwa to blisko $600 \mathrm{mld}$ zł, w tym: 144 mld zł warte są grunty w miastach, 129 mld - drogi i mosty, 98,5 mld zł - przedsiębiorstwa, w których Skarb Państwa ma stuprocentowe bądź częściowe udziały, 66 mld - lasy, a 14 mld - grunty rolne. Bardzo trudne do wyceny są dobra kultury (dzieła sztuki, muzealia, materiały biblioteczne, zabytki) oraz zasoby archiwalne. ${ }^{6}$

Ten olbrzymi majątek zarządzany jest „,w imieniu państwa” przez kilkadziesiąt tysięcy menedżerów wymienianych niemal w całości po kolejnych wyborach. Stanowiska traktowane są więc jako część łupu przynależnego zwycięskim partiom. W każdej z dotychczasowych koalicji władzy funkcjonowali tzw. personalni, czyli wpływowi politycy decydujący o obsadzie kluczowych stanowisk. Bardzo wyraźnie było to widać za czasów pierwszej koalicji SLD-PSL, po klęsce wyborczej środowisk solidarnościowych w 1993 r. „Personalni” w rolnictwie - na szczeblu centralnym, regionalnym i lokalnym - wywodzili się wówczas z PSL, a ,personalni” w przemyśle - z SLD.

W 1997 r. AWS (zrazu w parze z Unią Wolności) doszła do władzy pod hasłem walki z Rzeczypospolitą układów - i dość szybko zastapiła „kolesiów lewicy” - swoimi ludźmi. Przy tym w przedsiębiorstwach z udziałem Skarbu Państwa utrwalił się układ, zgodnie z którym pewna grupa menedżerów-fachowców, tych ze szczebla średniego wyższego (inżynierowie ds. produkcji, główni technolodzy, główni elektrycy, rzadziej główni księgowi), pozostaje niewymienna.

\footnotetext{
${ }^{4}$ Zatrudnienie w prywatnych przedsiębiorstwach poza rolnictwem wzrosło z 13,2\% w 1989 r. do niemal $60 \%$ ogółu zatrudnionych (wraz z rolnictwem i spółdzielczościa) już w 1992 r. Według danych z końca 1995 r. sektor prywatny wytwarzał ponad połowę PKB (za: H. Uścińska, Polityka gospodarcza, UG, Gdańsk 1997, s. 197).

${ }^{5}$ Por.: Raport Najwyższej Izby Kontroli pt. Wykonywanie przez Agencję Prywatyzacji zadań zleconych przez Ministra Skarbu Państwa, w zakresie prywatyzacji spótek i przedsiębiorstw państwowych. Czytamy w nim m.in.: „W toku kontroli stwierdzono także nieprawidłowości w pełnieniu przez Ministra Skarbu Państwa nadzoru właścicielskiego nad spółkami z udziałem Skarbu Państwa. Polegały one m.in. na nieuzasadnionym kwitowaniu reprezentantów Skarbu Państwa (...) w sytuacji ujemnych wyników finansowych i braku działań rady w kierunku jej poprawy, braku w ministerstwie dokumentacji umożliwiającej podejmowanie decyzji umożliwiających polepszenie sytuacji ekonomicznej [podległych spółek]”.

${ }^{6}$ Sprawozdanie o stanie mienia Skarbu Państwa, Ministerstwo Skarbu Państwa, Warszawa 2004, s. 3-6.
} 
Niezależnie od typu i klasy menedżera - po każdych wyborach i „naturalnej” wymianie rad nadzorczych i zarządów - można się spodziewać „najazdu Hunów”. Polega on na zupełnej wymianie firm współpracujących, a nawet, gdzie się da - dostawców. Najczęściej są to dostawcy usług (od finansowych po remontowe i czyszczące), doradcy, specjaliści od marketingu, promocji i public relations, rzadziej dostawcy surowców - bo tu często nie ma wyjścia; ale i w tym ostatnim wypadku często znajduje się sposób na podstawienie swoich - jako pośredników. Tworzy się też dziwne spółki-córki, inwestuje publiczne środki w prywatne podmioty oraz dotuje słuszne stowarzyszenia i fundacje.

Jednak w III RP ugruntowało się przekonanie, że - „w imię dobra i ludzi z natury dobrych” (co się nazywa „realizacją słusznych celów i koncepcji”) - żerować można, a nawet trzeba. Więc spółki z udziałem Skarbu Państwa wykładały już m.in. pieniądze na lewicowe tygodniki i prawicowe telewizje.

Liberalni twórcy pierwszych programów uzdrowienia polskiej gospodarki, na przełomie lat osiemdziesiątych i dziewięćdziesiątych XX w., obserwując sytuację w innych krajach, przewidywali, że pozostawienie politykom olbrzymiego wpływu na gospodarkę będzie owocować patologicznymi zjawiskami. Afery na styku polityki i gospodarki nie są przecież polską specyfiką; dochodziło do nich i dochodzi w społeczeństwach o dużo dojrzalszej demokracji i stabilnej ekonomii, głównie tam, gdzie pozwolono na nadmierny rozrost sfery publicznej.

Lekarstwem na zło miała być prywatyzacja. Liberałowie założyli, że żaden prywatny właściciel nie pozwoli na wymianę kompetentnego zarządu po jakichś wyborach, nie otworzy bramy „Hunom", nie będzie płacił haraczu partiom $\mathrm{i}$ ich regionalnym baronom.

W pierwszych czterech latach transformacji sprywatyzowano w Polsce bezpośrednio 753 przedsiębiorstwa, 595 skomercjalizowano, a 98 sprzedano pośrednio, po uprzednim przekształceniu w jednoosobowe spółki Skarbu Państwa. ${ }^{7}$ Po dojściu do władzy koalicji SLD-PSL w 1993 r. proces prywatyzacji, zwłaszcza bezpośredniej, został zasadniczo spowolniony, a po powtórnym objęciu rządów przez lewicę w 2001 r. - niemal się zatrzymał.

Lewicowcy postawili na komercjalizację, czyli przekształcenie przedsiębiorstw państwowych w jednoosobowe spółki skarbu państwa (JSSP), pozorując przygotowania do prawdziwej prywatyzacji. JSSP miały być tworami z założenia przejściowymi, powołanymi tylko po to, by udziały w nich mógł objąć (kupić) zewnętrzny inwestor. Te twory okazały się jednak dla etatystycznie nastawionych polityków bardzo poręczne, o wiele poręczniejsze niż przedsiębiorstwa państwowe. Te ostatnie funkcjonują na podstawie zupełnie innych przepisów - dają wielkie uprawnienia radom pracowniczym, gdyż są o wiele mniej sterowne. Natomiast JSSP podlegają kontroli ministra; to on fizycznie jest dla nich „walnym zgromadzeniem akcjonariuszy”, które powołuje radę nadzorczą. A taka rada wybiera do zarządu ,ludzi z natury dobrych”.

Za pierwszych rządów SLD po raz pierwszy na taką skalę - i tak otwarcie - w systemie pojawili się też pośrednicy prywatyzacyjni. Zaczęła obowiązywać zasada, że prywatyzacja jest możliwa tylko ,pod kontrolą państwa”, aby uniknąć ,wyprzedaży majątku narodowego”. W rzeczywistości chodziło o kontrolę prywatyzacji najciekawszych przedsiębiorstw przez grupy interesów.

Niemal we wszystkich wielkich polskich prywatyzacjach obok zachodnich inwestorów strategicznych pojawiają się mniejszościowi polscy partnerzy. Okazało się, że w Polsce nie sposób inwestować w browary, autostrady, energetykę, telekomunikację czy obrót paliwami bez udziału biznesmenów z odpowiednimi koneksjami.

\footnotetext{
${ }^{7}$ Stan 31.12.1993 r.; dane Ministerstwa Skarbu Państwa.
} 
System totalnego zawłaszczania i rozdziału stanowisk w przedsiębiorstwach oraz pośrednictwa w prywatyzacji, tak ostro krytykowany i atakowany przez ugrupowania tworzące w $1997 \mathrm{r}$. AWS oraz przez czołowych polityków Unii Wolności, bardzo się spodobał części działaczy obu tych formacji, kiedy te tylko doszły do władzy. Spodobał się do tego stopnia, że zamiast z nim walczyć (np. prywatyzując co się da), postanowili go oswoić. Użyć „w imię dobra”, czyli w interesie słusznych partii, ich równie słusznych działaczy oraz „krewnych i znajomych królika”.

Dzięki zakonserwowaniu systemu za czasów AWS, po sukcesie wyborczym w 2001 r. lewica mogła wrócić na stare śmieci i twórczo rozwijać układ. Zwyciężyło przekonanie, że jest to układ wieczny, a jego uczestnicy pozostaną na wieki wieków bezkarni, pod parasolem usłużnych prokuratorów i pozostałych organów śledczych i kontrolnych.

Dlaczego więc układ ,zaczął się sypać”? Są dwie teorie. Pierwsza, idealistyczna, mówi, że dobro i niezgoda na coraz bardziej doskwierające Polakom patologie zaczęły zwyciężać. Według drugiej teorii, realistycznej, układ „sypnął się” dlatego, że jego uczestnicy zaczęli się kłócić. Starzy gracze nadepnęli sobie na odciski, m.in. w walce o panowanie nad polską naftą: Orlenem, Rafinerią Gdańska, Naftoportem, infrastrukturą przesyłową i magazynową. Pojawili się też gracze nowi, którzy wskoczyli nagle z niższej półki na wyższą - i najwyraźniej zamierzali odgrywać rolę pośredników w największych prywatyzacjach (nie bez sukcesów!). Pomagali im w tym wpływowi politycy.

Doprowadziło to do chaosu w układzie, do przecieków i wzajemnych oskarżeń. Zgłodniali władzy politycy opozycji rzucili się na to z impetem. Dzięki temu poznaliśmy mechanizmy - i kulisy - podejmowania decyzji strategicznych dla gospodarki. Poznaliśmy też bliżej głównych bohaterów - tych z obszaru polityki, i tych z biznesu - oraz ich obyczaje.

W Raporcie otwarcia rządu Leszka Millera z 2002 r. omówiono niegospodarność oraz przestępcze działania zarządów 22 kluczowych firm z całkowitym lub większościowym udziałem państwa. Podano konkretne przykłady „najazdu Hunów”, wymieniono rozliczne sposoby wyprowadzania pieniędzy z firm, np. za pomocą dziwnych inwestycji w nieruchomości, egzotyczne prywatne spółki i ryzykowne przedsięwzięcia ${ }^{8}$. Skierowano doniesienia do prokuratury. Co czynili potem „ludzie Millera” - wiemy.

Jednak SLD jest pierwszą formacją, która na taką skalę przekonała się, że nie można na dłuższą metę głosić haseł ,ścigania przekrętów” i ,rozbijania układów władzy i biznesu” przy równoczesnym robieniu (własnych) przekrętów i utrwalaniu (swoich) układów - dla (lewicowego) dobra.

Nie jest pewne, czy SLD jest ostatnią formacją, która doznała takiego oświecenia.

\section{3. Źródła kryzysu i próba naprawy}

Od pewnego czasu wielu specjalistów, nie tylko sympatyków prawej strony sceny politycznej, przyznaje otwarcie, że źródła kryzysu III RP tkwią w epoce PRL-u, w wywodzących się z tego okresu układach, powiązaniach polityki i biznesu, a przede wszystkim w patologicznych mechanizmach przeniesionych w realia nowego państwa i konserwowanych z zapałem przez postkomunistów oraz przez formacje posolidarnościowe, które nie potrafiły się oprzeć pokusie zawłaszczania państwa dla siebie „w imię dobra”.

Lech i Jarosław Kaczyńscy oraz ich zwolennicy od lat twierdzili z uporem, że powodem kłopotów jest brak lustracji i dekomunizacji. Dzięki temu postkomuniści mogli do reszty zawładnąć gospodarką, a służby specjalne odgrywają w niej rolę, której odgrywać nie powinny.

\footnotetext{
${ }^{8}$ Informacja o sytuacji w wybranych spótkach Skarbu Państwa i przedsiębiorstwach państwowych. Raport otwarcia, Warszawa, 7.05.2002 r.
} 
Zdaniem liderów Prawa i Sprawiedliwości, ujawnione w Polsce afery z udziałem działaczy SLD (od Starachowic przez Łódź po Orlen) pozwalają twierdzić, że w przypadku tego ugrupowania tworzenie patologicznych, zgubnych dla państwa i społeczeństwa układów, w których triumfują korupcja i nepotyzm, jest normą. Paradoksalnie opinię tę podzielają młodzi członkowie SLD, którzy od pewnego czasu walczyli ze „starymi”, wywodzącymi się z PRL-u, a od chwili nastania rządów Wojciecha Olejniczaka przejmują stopniowo władzę w partii.

Pojawia się podstawowe pytanie: czy sama dekomunizacja i lustracja, wyeliminowanie z życia publicznego agentów i byłych komunistycznych aparatczyków automatycznie uzdrowi sytuację i pozwoli stworzyć podwaliny pod zdrowe państwo? Czy usunięcie ,nieuczciwych” i wstawienie w ich miejsce „uczciwych”, „ludzi z natury dobrych”-z rekomendacji PiS-u i ich sojuszników - będzie prawdziwym początkiem IV RP i pozwoli zapobiec kolejnej „zdradzie”?

Niewątpliwie czynnik ludzki wpływa na sytuację, w jakiej dziś się znaleźli Polacy, ale w rzeczywistości choroba III RP ma charakter systemowy. Nawet umieszczenie najświętszych ludzi w tym systemie nic nie pomoże, bo system ich zdeprawuje.

Zdaniem wielu analityków, nie tylko liberalnych, problemy Polski biorą się z nadmiernej siły państwa w dziedzinach, w których nie powinno być ono silne (np. w gospodarce) i jego słabości w sferach, w których jego siła jest niezbędna (np. w sądownictwie). Przy tym „siła państwa” oznacza w Polsce zbyt często „siłę polityków”, gdyż mają oni przemożny wpływ na obsadę kilkudziesięciu tysięcy stanowisk.

W Polsce od 16 lat, niezależnie od tego, która partia rządzi, powołuje się urzędników z klucza partyjnego. Skąd pokusa, której ulegli nawet politycy najbardziej wrodzy układom? Po pierwsze stąd, że partie są w Polsce słabe, a ich terenowe struktury jeszcze słabsze, więc nagminne stało się kupowanie działaczy i popleczników poprzez rozdawnictwo stanowisk w urzędach oraz w spółkach od nich zależnych. Po drugie - polscy urzędnicy wszelkich szczebli są dziś uzbrojeni w chore prawo: niejasne, skomplikowane, uznaniowe. To broń, która bywa bardzo poręczna dla rządzących a zabójcza dla ich politycznych konkurentów, a przy okazji dla przeciętnych obywateli. Bo jeśli urzędnik, zgodnie z prawem, coś „może”, to nie oznacza, że „musi”. I od razu pojawia się korupcjogenne pytanie: jak go do czegokolwiek nakłonić?

Sztandarowym przykładem mętności i uznaniowości przepisów stało się prawo podatkowe. Obywatel nie jest w stanie uzyskać od urzędu skarbowego wiążącej interpretacji przepisów; nawet zastosowanie się do urzędowej interpretacji nie oznacza, że za kilka lat nie zostanie za to ukarany potężną grzywna, aresztowaniem, skasowaniem firmy, przepadkiem majątku.

Polska nie dorobiła się przepisów, które pozwoliłyby skutecznie karać urzędników za łamanie prawa i szkodzenie obywatelom; nie ma też sądownictwa, które skutecznie broniłoby ludzi przed bezprawiem urzędniczej machiny. Co z tego, że petent (podatnik) dowiedzie swoich racji w sądzie, skoro dzieje się to zbyt późno, po dwóch, trzech, pięciu latach? Firmy nie ma, majątku nie ma, nie ma pracy.

Zdaniem części przedsiębiorców, system niejasnego, uznaniowego prawa został stworzony celowo. $Z$ jednej strony daje on olbrzymią władzę urzędnikom, a więc i pociagającym za sznurki politykom. Z drugiej - pozwala dobrze żyć przeróżnym doradcom, którzy często tworzą maksymalnie zawiłe przepisy, by je potem odpłatnie tłumaczyć.

Dlaczego nie da się tego zmienić? Bo potężna grupa ludzi jest zainteresowania działaniem we mgle. Takich ludzi, którym złe prawo daje władzę i wielkie pieniądze. Żadna z rządzących ekip, mimo głoszonych haseł, nie potrafiła się tej grupie przeciwstawić. Raczej wchodziła w buty poprzedników, w dziwne układy, i korzystała z systemu. 
Zwolennicy utworzenia IV RP zakładają, że jeśli powołają na stanowiska odpowiednich ludzi, oni zrobią porządek i odbudują zaufanie obywateli do instytucji publicznych. Jednakże działacze LPR i PiS rządzą od kilku lat w wielu gminach i regionach, a mało gdzie widać zmianę jakości i reguł funkcjonowania instytucji publicznych. Niemal wszystkie „stołki” są nadal obsadzane z partyjnego klucza.

W wielu wypadkach lokalne układy i mechanizmy funkcjonowania instytucji przechodzą po prostu z rąk do rąk, w wielu miejscach ,grupy trzymające władzę" nie mają nawet zabarwienia politycznego; to po prostu lokalne grupy interesów. Nie do rozbicia od lat.

Ogromna część społeczeństwa przyzwala na łapownictwo i sama w nim na co dzień uczestniczy. Dlatego niektóre informacje o korupcji i innych zachowaniach uznawanych w demokratycznych krajach za naganne i niedopuszczalne, w Polsce nie budzą reakcji. To sprzyja bezkarności.

\section{Wnioski końcowe}

Mamy w Polsce do czynienia z demokracją okazjonalną. Ludzie jednoczą się niemal wyłącznie wokół wspólnych dramatów i tragedii. Tylko wtedy korzystają z prawa głosu. Nasze społeczeństwo może symbolizować Wielka Orkiestra Świątecznej Pomocy: w jednym dniu w roku wykazujemy się bezprecedensową odpowiedzialnością, solidarnością, ofiarnością. Ale od lat nie potrafimy rozwiązać całościowo problemu opieki zdrowotnej. I tak jest ze wszystkim. Pozostajemy wielką orkiestrą powszedniej niemocy.

I nie możemy wszystkiego zwalać na polityków. Bo to my ich kreujemy i wybieramy; brak głosu w wyborach to też jest wybór, niczym oddanie meczu walkowerem.

Czy z demokracji okazjonalnej może się wyłonić ta prawdziwa, dojrzała, polegająca na gremialnym uczestnictwie w wyborach i świadomym oddawaniu głosów na partie gwarantujące stabilny rozwój kraju? Tak. Ludzie zjednoczeni wokół różnych spraw: poszkodowani przedsiębiorcy, konsumenci, pacjenci, ofiary nieuczciwych deweloperów i spółdzielni mieszkaniowych dostrzegają coraz częściej, że powodem ich nieszczęść są nie tyle ludzie złej woli, co mechanizmy, które pozwalają tym ludziom na zgubne w skutkach, czasem bandyckie działanie. Próbują więc zmienić mechanizmy i w wielu sprawach, po ciężkich bojach udaje się to zrobić. ${ }^{9}$

Zwolennicy budowy IV RP uważają, że narzucenie nowych reguł nie będzie możliwe bez wzmocnienia państwa, co rozumieją jako zwiększenie roli, wpływu i kontroli ze strony rządzących polityków (w domyśle „ludzi z natury dobrych”), prawych, uczciwych, solidarnych, „którzy zrobią porządek” i ,nikogo nie zdradzą".

Liberałowie twierdzą z uporem, że to jest kolejna powtórka z utopii i przygrywka do następnej, nieuchronnej ,zdrady”. I chcą ograniczać wpływ polityków na życie gospodarcze i społeczne do niezbędnego minimum.

Już dziś część politologów ocenia, że mamy w Polsce do czynienia z ,państwem drapieżczym” (ang. predator state) ${ }^{10} \mathrm{Czy}$ wobec tego można twierdzić, że wzmacniając je, zbudujemy naprawdę nową Rzeczpospolitą, w której państwo będzie się zachowywać zgodnie z oczekiwaniami większości obywateli? Słowem: czy dozbrajanie drapieżcy to dobry pomysł?

\footnotetext{
${ }^{9}$ Przykładami są m.in.: Ustawa o gwarancji zapłaty za roboty budowlane z 9.07 .2003 r. (DzU Nr 180, poz. 1758) oraz Ustawa o zmianie ustawy Kodeks cywilny oraz niektórych innych ustaw z 14.02.2003 r. (DzU Nr 49, poz. 408).

${ }^{10}$ Określenie to pojawia się m.in. w publicystyce i wypowiedziach prof. Marcina Króla; więcej o tym pojęciu: A. Baigorri, From Predator state to sustainable region, University of Estremadura in Badajoz, Badajoz 1999.
} 
Przecież na pierwszy rzut oka widać, że powodem kryzysu III RP nie jest słabość państwa, lecz brak jawności i nieprzejrzystość reguł, które nim rządzą. Tajne są kryteria i wyniki przetargów i umów prywatyzacyjnych, niejasne są zasady obsadzania stanowisk w gospodarce i w urzędach. Niemal od początku III RP dzieje się to z partyjnego klucza; nie wiadomo, dlaczego jednym firmom państwo (lub samorząd) umarza długi, a innym nie, dlaczego jednych przedsiębiorców ściga się do upadłego (dosłownie), a innych hołubi, dlaczego jedni dostają pozwolenie (koncesję), a inni nie. Żaden z dotychczasowych rządów, mimo często szumnych zapowiedzi, nie potrafił zmienić tej sytuacji. A bez zmiany w tym zakresie wszelkie inne zmiany będą pozorne.

Potrzebna jest niezależna od partii służba cywilna w urzędach; potrzebni są niezależni, wyłonieni w otwartych konkursach menedżerowie na kontraktach w przedsiębiorstwach Skarbu Państwa; niezbędne są przejrzyste i możliwie proste przepisy niezawierające zwrotu „urząd może”. Obecnie polską przedsiębiorczość dusi gorset ponad 600 koncesji zapisanych w ponad 1700 ustaw i rozporządzeń, przez które tak wiele w Polsce zależy od urzędniczego widzimisię, czyli w praktyce od partyjnego układu sterującego urzędnikiem.

I PiS, i PO deklarują zdecydowane działania w tym kierunku. Platforma Obywatelska chce odbiurokratyzować gospodarkę i generalnie wydrzeć ją z rąk rządzących partii, PiS chce zbudować przejrzyste i zdrowe państwo. Czy - wobec obecnego apetytu części działaczy - uda się ten mechanizm zastosować w skali państwa? Czy kontrolą pracy urzędników i menedżerów przestaną się zajmować partyjni towarzysze, a zaczną niezależne i niezawisłe, a przy tym sprawne organy państwa (w tym sądy), opierające się na jasnym i przejrzystym prawie? Czy Polska wyjdzie w końcu z gęstej, nieprzeniknionej mgły, w której możliwe są, z jednej strony, niejasne układy, powiązania korupcyjne i przekręty, a z drugiej - polityczne naciski na urzędników: słabych, niekompetentnych, zależnych od partyjnych mocodawców?

Teoretycznie taki cel stawiają sobie nie tylko zwycięzcy wyborów, lecz także LPR i SLD. Po klęsce Leszka Millera jego następca Marek Belka uznał odpartyjnienie urzędów, nie tylko centralnych, ale i samorządowych, za jedno z podstawowych i najpilniejszych działań dla dobra Polski ${ }^{11}$. Pozostawiony następcom projekt zawiera klarowne zasady naboru pracowników nie tylko do urzędów, ale i do agencji, funduszy, instytucji ubezpieczeń społecznych. Jest nawet mowa o modelu skandynawskim, w którym ujawniane są kompletne dokumentacje dotyczące konkursów na stanowiska, przetargów czy decyzji władz w sprawach podatkowych (np. ulg dla firm). W przypadku Marka Belki na deklaracjach się skończyło. Opór materii okazał się zbyt wielki. Dotychczas politycy nie chcieli ,wypuścić z rąk konfitur”. Czy po 16 latach wypuszczą?

Wielu z nas łudzi się, że z chocholego tańca obudzi nas nowe pokolenie, wychowane w III RP, świeże, nieobciążone zgubnymi przypadłościami PRL-u. W jego wykształcenie inwestujemy olbrzymie pieniądze: publiczne i coraz częściej prywatne, $\mathrm{z}$ trudem wysupłane $\mathrm{z}$ domowych budżetów. Ale w atmosferze niemocy i niewiary w możliwość odmiany III RP większości obywateli, wielu młodych, również tych najlepiej wykształconych, próbuje szukać swojej szansy w innych krajach. Zamiast zmieniać Polskę, zamierzają budować lepsze Niemcy, lepsze Stany Zjednoczone i lepszą Wielką Brytanię.

\footnotetext{
${ }^{11}$ Wystapienie premiera Marka Belki w sejmie w związku z pierwszym czytaniem rządowych projektów nowelizacji: ustawy o służbie cywilnej, ustawy o pracownikach administracji samorządowej oraz ustawy o przeprowadzaniu konkursów na stanowiska kierowników centralnych urzędów administracji rządowej, prezesów agencji i funduszy państwowych, Warszawa, 3.11.2004 r.
} 
Rządzący powinni pamiętać, że niemal wszyscy dotychczasowi triumfatorzy wyborów mieli usta pełne etyki oraz wspaniałe plany w chwili walki o władzę, i szybko sprzeniewierzali się temu po jej objęciu. Nie dlatego, że okazali się „ludźmi z natury złymi”, jak nas przekonywali i długo jeszcze będą przekonywać ich prący do władzy przeciwnicy, ci ,z natury dobrzy”. „Zdrada” wszystkich rządzących III RP polegała na tym, że ulegli oni pokusie korzystania z przejętej sieci układów, całego systemu etatystycznego państwa, zamiast to państwo przebudowywać i zmieniać.

\section{Literatura}

1. Baigorri A., From Predator state to sustainable region, University of Estremadura in Badajoz, Badajoz 1999.

2. Belka M., Hausner J., Jasiński L.J., Marody M., Zirk-Sadowski M., Polska transformacja w perspektywie integracji europejskiej, Wydawnictwo Fundacja F. Eberta, Warszawa 1996.

3. Informacja o sytuacji w wybranych spótkach Skarbu Państwa i przedsiębiorstwach państwowych. Raport otwarcia, Warszawa, 7.05.2002 r.

4. Król M., Decentralizacja po polsku, „Tygodnik Powszechny”, 10.08.2003 r.

5. Przebieg procesów przekształceń własnościowych. Raport Ministerstwa Skarbu Państwa, Warszawa 2005.

6. Sprawozdanie o stanie mienia Skarbu Państwa na dzień 31 grudnia 2003, Ministerstwo Skarbu Państwa, Warszawa 2004.

7. Ustawa o gwarancji zapłaty za roboty budowlane z 9.07.2003 r. (DzU Nr 180, poz. 1758).

8. Ustawa o zmianie ustawy Kodeks cywilny oraz niektórych innych ustaw z 14.02.2003 r. (DzU Nr 49, poz. 408).

9. Uścińska H., Polityka gospodarcza, Uniwersytet Gdański, Gdańsk 1997.

10. Wykonanie przez Agencję Prywatyzacji zadań zleconych przez Ministra Skarbu Państwa w zakresie prywatyzacji spótek $i$ przedsiębiorstw państwowych. Raport Najwyższej Izby Kontroli, Warszawa 2003.

11. Wystapienie premiera Marka Belki w Sejmie w zwiqzku z pierwszym czytaniem rzqdowych projektów nowelizacji: ustawy o stużbie cywilnej, ustawy o pracownikach administracji samorzqdowej oraz ustawy o przeprowadzaniu konkursów na stanowiska kierowników centralnych urzędów administracji rzqdowej, prezesów agencji i funduszy państwowych, Warszawa, 3.11.2004 r.

\section{Seduction of Statism. How Much Politics Is in the Economy? Ethical Aspect}

This article tries to answer to the questions about how politics and politicians influenced Polish economy in the last sixteen years, and in what direction the changes at the border between politics and economy are going on. Ethical results of various attitudes toward this problem were critically compared, emphasizing views of advocates of liberalism and statism. 